\title{
ENVIRONMENTAL RISK DETERMINATION OF FLOOD IN PORSUK RIVER BASIN VIA ONE-DIMENSIONAL MODELLING
}

\author{
KARAER, F. ${ }^{1 *}-$ KOPARAL, A. S. ${ }^{1}-$ TOMBUL, ${ }^{2}{ }^{2}$ \\ ${ }^{1}$ Department of Environmental Engineering, Faculty of Engineering, Anadolu University \\ Eskisehir, Turkey \\ ${ }^{2}$ Department of Civil Engineering, Faculty of Engineering, Anadolu University \\ Eskisehir, Turkey \\ *Corresponding author \\ e-mail:fadimek@anadolu.edu.tr \\ (Received $12^{\text {th }}$ Jan 2018; accepted $17^{\text {th }}$ Jul 2018)
}

\begin{abstract}
Floods, which are frequently occurring natural disasters, may interrupt the social and economic activities, and cause serious environmental and health problems in the region under effect. Floods may cause environmental problems such as soil loss, pollution of fresh water resources and epidemic diseases transported by floodwater. In order to prevent these adverse effects, flood risk maps, flood prevention and sustainable flood management plans must be established at the settlements which are vulnerable to floods. In this study the flood frequency analysis of Porsuk River basin located between the Porsuk Dam (which is the only source of domestic water of the city) and Eskisehir city center was conducted. The return period and probability distribution of flood magnitude were identified by flood frequency analysis. The effects of floods on the region located between the Porsuk Dam and Eskisehir city center were examined, the probable maximum flood for 25, 50, 100, and 500 years of flood return periods were determined by Log Pearson III method using the maximum flow data of years 1963-2009. MIKE 11 was presented in this study as one-dimensional flood model, which was conducted to determine the flood risk with efficient, easy and quick decision making approaches in Turkey.
\end{abstract}

Keywords: flood risk, flood frequency analysis, flood modelling, one-dimensional modelling, MIKE 11, flood mapping

\section{Introduction}

Floods are listed between natural disasters with huge detriment forces because of their adverse effects on environment, health and economy in vulnerable areas (Düzgün, n.d.; Uşkay and Aksu, 2002). In environmental aspect, floods affect biodiversity of flora and fauna (Tingsanchali and Karim, 2005), cause soil depletion (Uşkay and Aksu, 2002), pollute surface water sources (Haltaş, 2013), create epidemic disasters by infectious microorganisms and death (Çetin, 2013). Also, floods have social impact, such as, physiologic health problems caused by natural disaster, and the damaging of historical buildings and economic effects (Morss et al., 2005).

Recently, focus has shifted towards developing most appropriate strategies, including the promotion of vulnerability assessment and development of skills, methods and technologies to cope with flood, the assessment of costs and benefits and flood management methods (Calder and Aylward, 2006; Zhang et al., 2008; Marchi et al., 2010; Merz et al., 2010). Floods Action Program and Directive on The Assessment and Management of Flood Risk (2007/60/EC) was published by European Parliament in October 2007 to create general frame politics of water bodies', develop flood management plans for every basin areas, and aim reducing the devastating effect of floods (Griffiths, 2002). The major goals of the directive are both decreasing food risks 
and determining possible effects caused by climate changes (Brown and Damery, 2002). In line with the Flood Action Programme, Ministry of Forestry and Water Affairs in Turkey organized National Basin Management Framework (NBMF) with aim to protect water basin, sustainable and profitable usage of water resources, and providing guidance to investment programs engendered as a result of long-term discussions with different institutes with different views (Çetin, 2013; Hopur, 2013; Ün, 2013). Under the scope of NBMF, the Ministry planned to create twenty five basin management committees including local authorities, universities, civil organizations, and other foundations and these committees provide the implementation of the principles of NBMF in order to prevent the adverse effects caused by the floods on the environment, generate flood risk maps, and establish flood prevention and sustainable flood management plans (Düzgün, n.d.; Akpinar, 2013; Aras, 2013).

The evaluation of increased flood risk has been investigated among engineers and economists. The areas under the flood risk are determined with the return period, the water depth and the flowrate of flood (Düzgün, n.d.; Uşkay and Aksu, 2002: Tiryaki, 2013). Different hydraulic models such as one-dimensional hydraulic models (1-D), two-dimensional hydraulic models (2-D), and integrated hydraulic models (1D-2D) can used to investigate flood risk. HEC-RAS (Özdemir, 2013), HEC-GEORAS (Özdemir, 2013) and MIKE 11 (Thompsona, 2004; Patro et al., 2009) 1-D hydraulic models are performed to determination the water depth of flood with the flowrate and the return period along the rivers and canals. 2-D hydraulic models can be listed MIKE 21, FLO2D, and CCHE2D providing flood depth with cross-section area along the rivers and canals. The integrated models like MIKE FLOOD (Liu et al., 2007; Patro et al., 2009) combine both 1-D hydraulic models (MIKE 11) and 1-D hydraulic models (MIKE 21) to determine flooded area settled around the rivers and canals.

MIKE 11 is a 1-D modelling system for rivers, channels, reservoirs and structures. The model is a world standard in 1-D river modelling for simulating flow and water level, water quality and sediment transport in rivers, floodplains, irrigation canals and other inland water bodies. The model application range is large enough to include simple design investigation and huge forecasting projects requiring complex hydraulic structure operation policies as well (Thompsona, 2004; Patro et al., 2009). This model is a versatile modelling platform enabling hydrodynamic modelling of rivers, irrigation systems, flood control, advection dispersion modelling, water quality modelling and sediment transport modelling (Tingsanchali and Karim, 2005; Marchi et al., 2010; Wen, 2013; Wolfs, 2013).

The structure of the model includes data and modules of the basin such as, rainfallrunoff data, river hydrodynamics, advection-dispersion data, water quality, topographical data and time series data of the river. The topographical data are the channel cross-section, the floodplain topography, the roughness and the structure geometry, Time series data are the boundary conditions of the river, the water levels, the discharges and the Q-h boundary data of the river. Modelling of unsteady flow via MIKE 11 is based on three fundamental elements, which are a differential relationship expressing the physical laws, a finite difference scheme producing a system of algebraic equation, and a mathematical algorithm to solve these equations. MIKE 11 general assumptions are listed below:

- Incompressible and homogeneous fluid,

- The flow is one-dimensional (uniform velocity and water level in crosssection), 
- The bottom slope is small,

- Small longitudinal variation in geometry, and

- Hydrostatic pressure distribution.

This paper presents an approach that can be used to identify flood risk and creating flood risk map in Porsuk River basin. According to flood risk assessment framework introduced to our country by EU Flood Risk Directive, this study can demonstrate an integrated approach used to determine flood impact assessment, flood modelling, economic tool, and risk assessment. The method, MIKE 11 was presented in this study, can be considered as an important, easy and quick decision support tool that can develop existing decision making approaches like HEC-RAS, which are generally used for flood risk in Turkey. Also, this study will be useful in design of dams, culverts and flood control structures in the mentioned area in relation to urban drainage, river basin and canals.

\section{Materials and methods}

In this study the flood frequency analysis, the return period and probability distribution of flood magnitude were identified by flood frequency analysis for Porsuk River basin. The one-dimension flood modelling was performed on the region located between the Porsuk Dam and Eskisehir city center. The probable maximum flood of flood return periods were determined using the maximum flow data.

\section{Working area}

The project area selected in this study is located in Porsuk River basin. The Porsuk River is the sub basin of Sakarya River basin, and covers an area of $11325 \mathrm{~km}^{2}$ in the northwest Anatolia Basin. The basin is located between 29 $38^{\prime}-31^{\circ} 59^{\prime}$ east longitude and $38^{\circ} 44^{\prime}-39^{\circ} 99^{\prime}$ north latitude and has $202 \mathrm{~km}$ in length to the East-West direction and $135 \mathrm{~km}$ in length to the North-South direction. The Basin contains Eskisehir and Kutahya centers, and the 7 district of these two cities and some parts of it can be bordered by Ankara, Usak and Afyon borders. More than $60 \%$ of the basin is mountainous. The project area has been identified between area of Eskisehir and Porsuk Dam and it covers an area of $4253 \mathrm{~km}^{2}$. The project area is shown in Figure 1 and its properties between the town and dam are listed in Table 1 .

Table 1. The project area properties in the Porsuk River basin

\begin{tabular}{c|c}
\hline Property & Value \\
\hline X (top left) & 107951.11978 \\
Y (top right) & 143651.70000 \\
X (bottom left) & 111378.88022 \\
Y (bottom right) & 141963.30000 \\
West longitude & $29^{\circ} 59^{\prime} 11.1198^{\prime \prime} \mathrm{E}$ \\
North longitude & $39^{\circ} 54^{\prime} 11.7000^{\prime \prime} \mathrm{N}$ \\
East longitude & $30^{\circ} 56^{\prime} 18.8802^{\prime \prime} \mathrm{E}$ \\
South longitude & $39^{\circ} 26^{\prime} 3.3000^{\prime \prime} \mathrm{N}$ \\
Scale & $1: 156700$ \\
Area & $4253.1 \mathrm{~km}^{2}$ \\
\hline
\end{tabular}




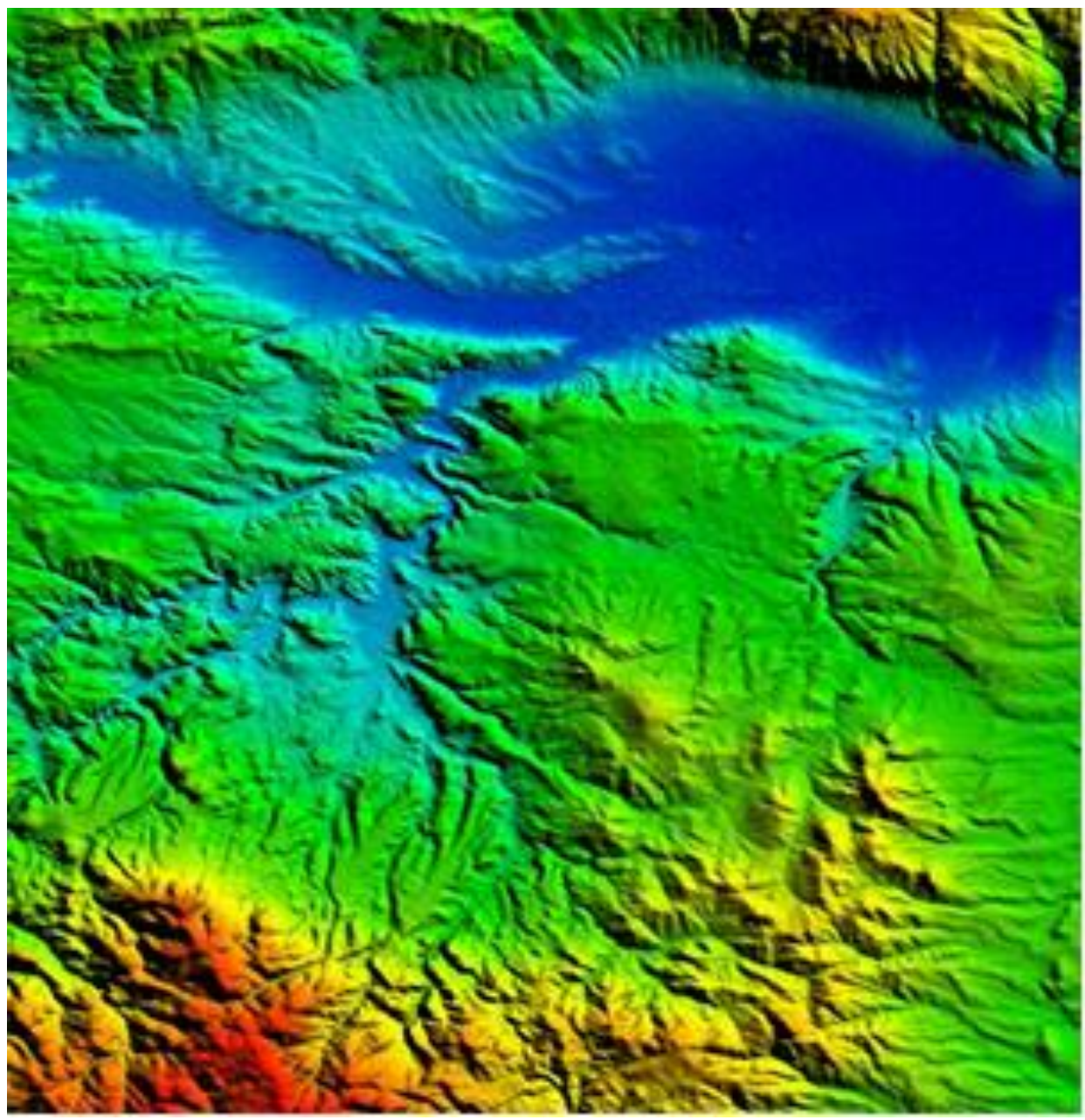

Figure 1. The project area in the Porsuk River basin

\section{Determination of flood return period in Porsuk River basin}

The return period and probability distribution of flood magnitude were identified by flood frequency analysis. The effects of floods on the region located between the Porsuk Dam and Eskisehir city center were examined, the probable maximum flood for 25, 50, 100, and 500 years of flood return periods were determined by Log Pearson III method using the maximum flow data of years 1963-2009 (47 years period) provided by The State Hydraulic Works in Turkey.

\section{MIKE 11-one dimension flood modelling}

MIKE 11 (MIKE, DHA 2012 SOFTWARE) 1-dimensional simulation software is composed of four subfiles associated with the data files. These files are the network data for the river line, the river cross-section file, and the boundary data file of the study area boundary conditions, and the files of river hydrodynamic parameters. The file of river hydrodynamic parameters has been identified as high-order full dynamic. After entering the files associated with the sub-model to simulation model, 1D simulation models was performed with prepared data by the return period of flood. MIKE 11 model setup is shown in Figure 2. 


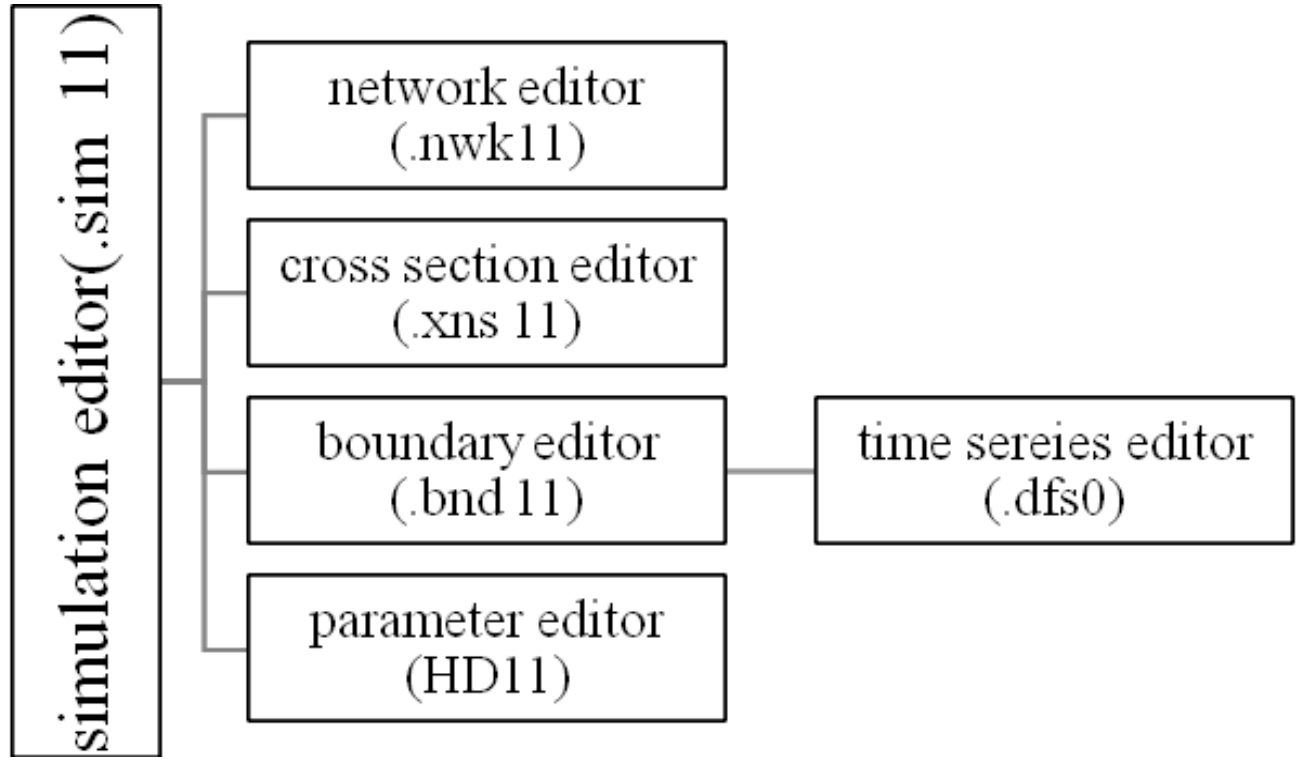

Figure 2. MIKE 11 model setup

To perform, MIKE 11 with data of Log Pearson III methods, a background map of the study area, the shape files map contains the river line, the field measurement data including the river cross-section, the data with the topographic heights of the study area, the boundary conditions for the workspace to create a terrain mesh and the flood periods files of the water level and the height of the flood flow were prepared. A background map (bacground.gif) for the work area to create the model grid, the shape file map (network.shp) containing the Porsuk River line, the site measurement data (surveyed_cross-section.txt) containing river sections, the topographic heights of the study area (dem.xyz), the boundary conditions for the study area and the water level heights of the floods and the floods were prepared as sub-file entrance data to run simulation model for MIKE 11.

Firstly, a background map of the working area was digitized by the manual marking method in the file containing the river line data in network editor (. nwk 11), the representation on the associated background file was shown in Figure 3 after digitizing. The section data obtained by field measurements previously was transferred to the file containing the data for the river section line (. xns 11), the graphs of the processed and unprocessed section data are shown in Figure 4. Manning's n value for the river line was chosen as 0.025 .

The existing water level was used as the downstream limit condition in the file containing the boundary conditions of the river lines (. bnd 11), triangular hydrographs of $65,124,166,220,261,309,408,450 \mathrm{~m}^{3} / \mathrm{s}$ and the peak condition with one-hour interval calculated by respectively 2, 5, 10, 25, 50, 100, 200, 500 and 1000 years flood frequency period, was used as the upstream limit condition. The sample hydrograph constructed for a 2-year periodic renewal was shown in Figure 5. In the file containing the hydrodynamic parameters, the wave approximation is defined as "high order full dynamics". After the sub files created by using the prepared model bases were associated with the simulation file, 1-dimensional models were created by entering the simulation period of the flood flowrates. 


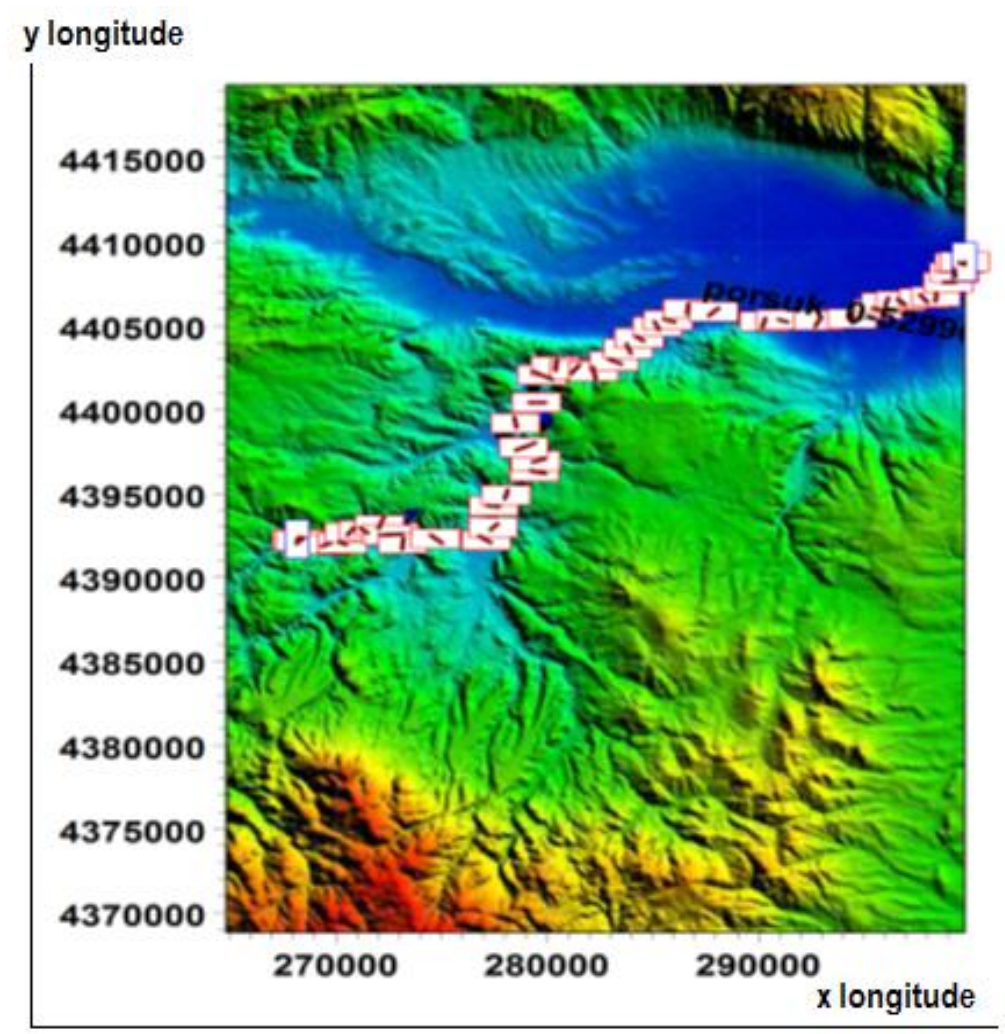

Figure 3. Project area in the Porsuk River basin with digitized cross section in $x$ and $y$ longitudes with dimensionless along the river (boxes refer processed cross section with $n$ : $0.025)$

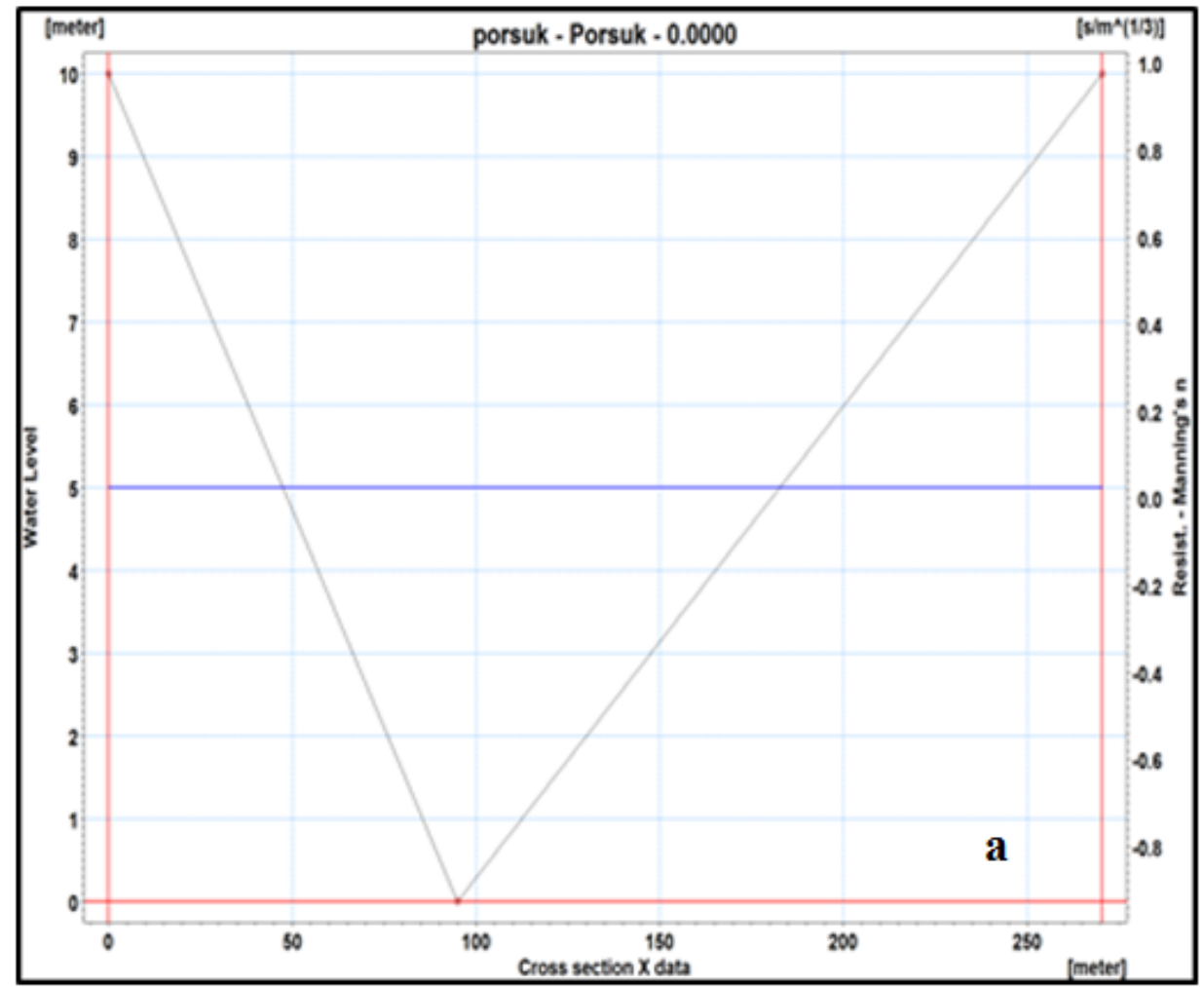

APPLIED ECOLOGY AND ENVIRONMENTAL RESEARCH 16(4):4969-4983. http://www.aloki.hu • ISSN 15891623 (Print) • ISSN 17850037 (Online) DOI: http://dx.doi.org/10.15666/aeer/1604_49694983 (c) 2018, ALÖKI Kft., Budapest, Hungary 


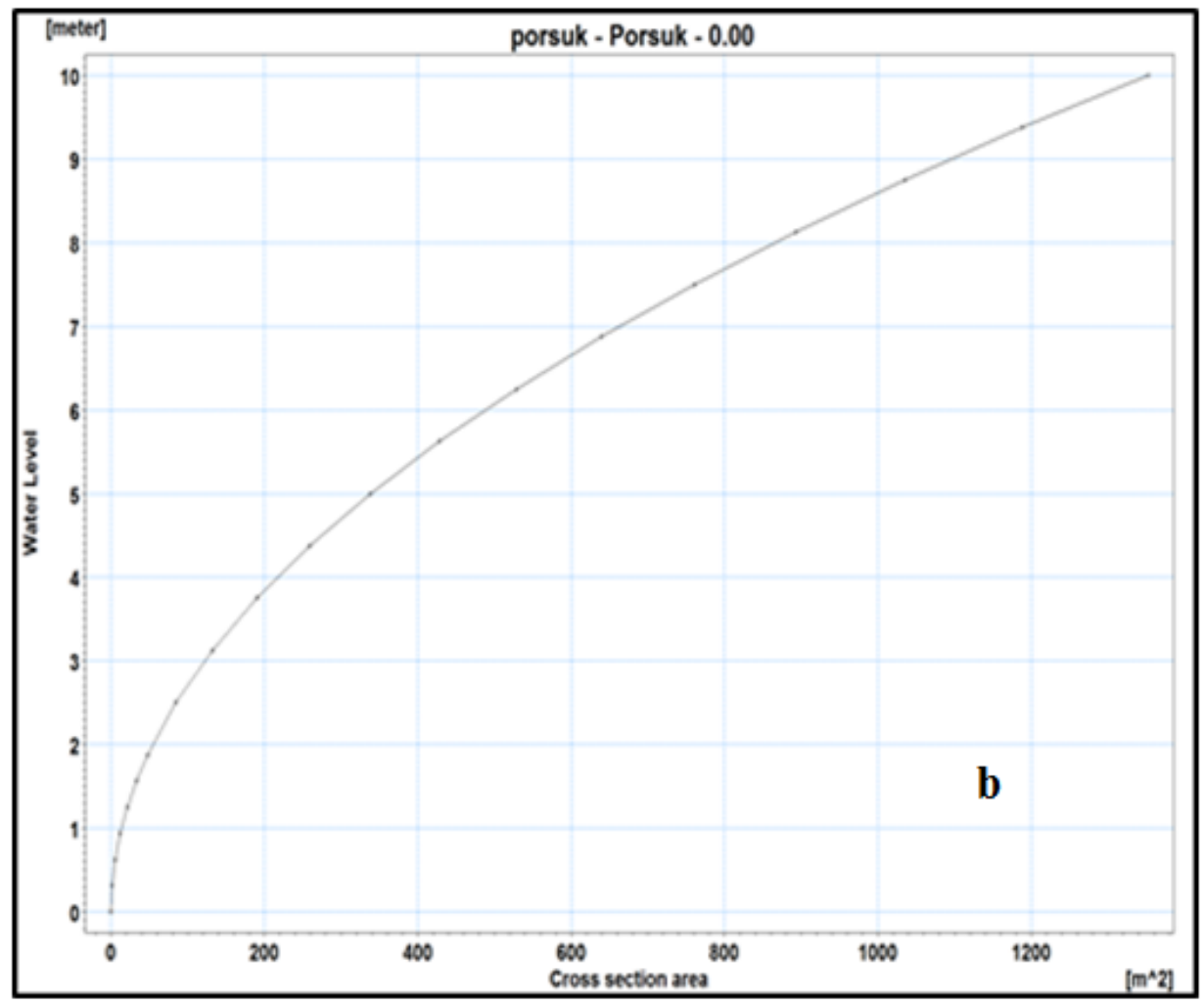

Figure 4. a Unprocessed section data. $\boldsymbol{b}$ Processed section data

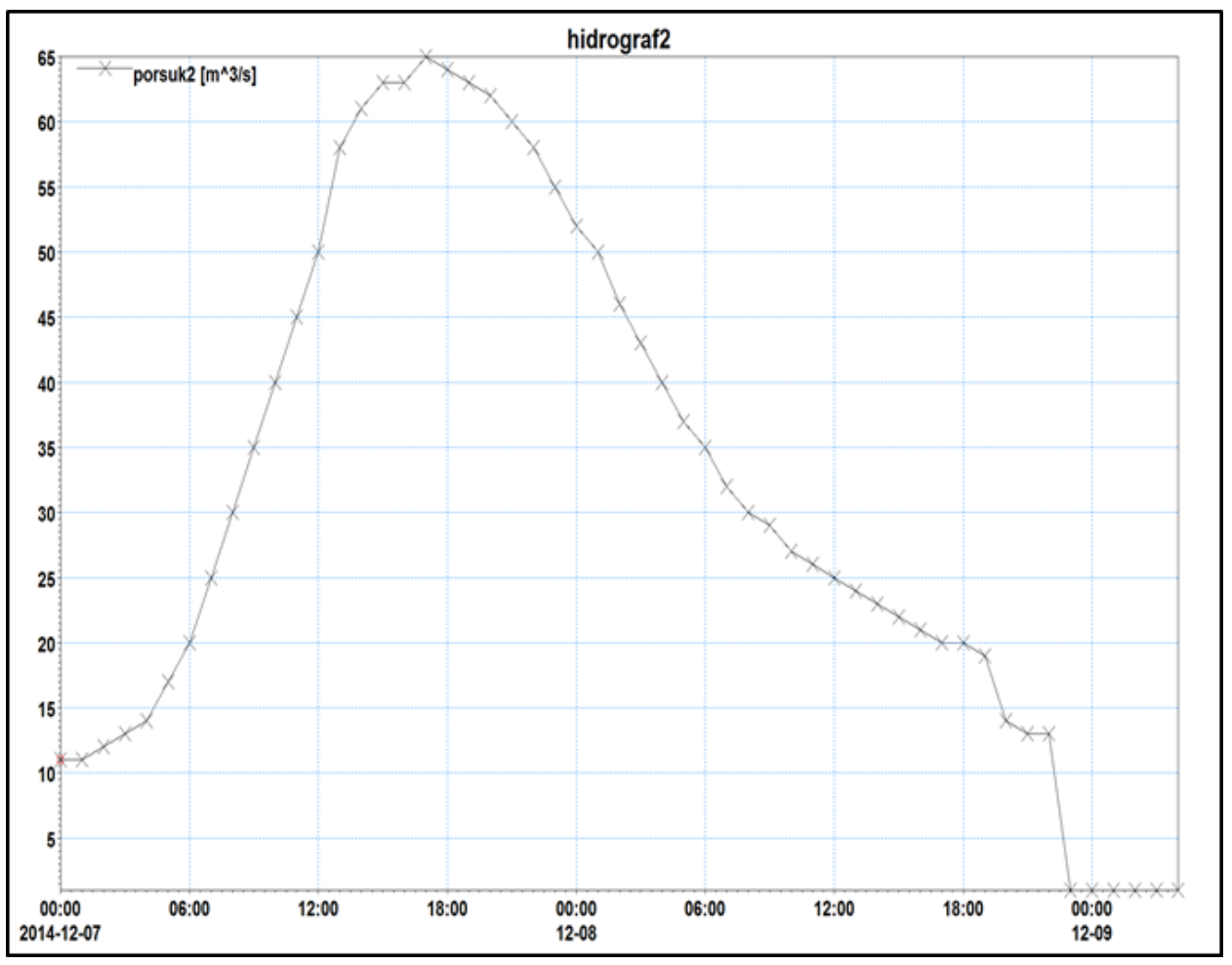

Figure 5. The sample hydrograph constructed for a 2-year periodic renewal 


\section{Results}

\section{Results of flood return period analysis}

The return period and probability distribution of flood magnitude were identified by flood frequency analysis in the region located between the Porsuk Dam and Eskisehir city. The probable maximum flood return periods were determined by Log Pearson III method using the maximum flow data of years 1963-2009 (47 years period) provided by State Hydraulic Works in Turkey. The results of the flood return period analysis are given in Table 2.

Table 2. Results of flood return period analysis

\begin{tabular}{c|c|c|c|c|c}
\hline $\boldsymbol{i}$ & $\begin{array}{c}\text { Return period } \\
\text { (years) }\end{array}$ & Possibility $\boldsymbol{P}(\boldsymbol{\%})$ & $\begin{array}{c}\text { Frequency } \\
\text { coefficient }(\boldsymbol{K})\end{array}$ & $\boldsymbol{Y = \operatorname { l o g } ( \boldsymbol { Q } )}$ & $\begin{array}{c}\text { Flood flow rate } \\
\boldsymbol{Q}\left(\mathbf{m}^{\mathbf{3}} / \mathbf{s}\right)\end{array}$ \\
\hline 1 & 2 & 50 & 0.296 & 2.232 & 480 \\
2 & 5 & 20 & 0.786 & 2.921 & 834 \\
3 & 10 & 10 & 0.916 & 2.985 & 966 \\
4 & 25 & 4 & 0.991 & 3.022 & 1051 \\
5 & 50 & 2 & 1.018 & 3.035 & 1083 \\
6 & 100 & 1 & 1.031 & 3.041 & 1100 \\
7 & 200 & 0.5 & 1.038 & 3.045 & 1108 \\
8 & 500 & 0.2 & 1.044 & 3.047 & 1115 \\
9 & 1000 & 0.1 & 1.045 & 3.048 & 1117
\end{tabular}

As a result of flood return period analysis, the lowest flood flowrate is $480 \mathrm{~m}^{3} / \mathrm{s}$ and the return period is 2 years with $50 \%$ possibility. The biggest flood flowrate is $1117 \mathrm{~m}^{3} / \mathrm{s}$ and the return period is 1000 years with $0.1 \%$ possibility. 52-h flow rate based on the flood return period and their flowrates was used for MIKE 11 simulation. The 52-h calculated flowrates used in simulations were given in Table 3.

Table 3. 52-h flow rate based on the flood return period and their flow rates

\begin{tabular}{c|c|c|c|c|c|c|c|c}
\hline \multirow{2}{*}{ t (hour) } & \multicolumn{7}{|c}{ Return period (years)/flow rates Q $\left.\mathbf{( m}^{\mathbf{3}} / \mathbf{s}\right)$} \\
\cline { 2 - 9 } & $\mathbf{2 / 4 8 0}$ & $\mathbf{5 / 8 3 4}$ & $\mathbf{1 0 / 9 6 6}$ & $\mathbf{2 5 / 1 0 5 1}$ & $\mathbf{5 0 / 1 0 8 3}$ & $\mathbf{1 0 0 / 1 1 0 8}$ & $\mathbf{5 0 0 / 1 1 1 5}$ & $\mathbf{1 0 0 0 / 1 1 1 7}$ \\
\hline $\mathbf{0}$ & 11.00 & 11.00 & 11.00 & 11.00 & 11.00 & 11.00 & 11.00 & 11.00 \\
\hline $\mathbf{1}$ & 11.13 & 11.30 & 11.41 & 11.56 & 11.68 & 11.81 & 12.08 & 12.20 \\
\hline $\mathbf{2}$ & 11.67 & 12.49 & 13.06 & 13.80 & 14.38 & 15.03 & 16.39 & 16.98 \\
\hline $\mathbf{3}$ & 12.60 & 14.58 & 15.96 & 17.73 & 19.11 & 20.69 & 23.96 & 25.37 \\
\hline $\mathbf{4}$ & 14.38 & 18.53 & 21.44 & 25.17 & 28.08 & 31.40 & 38.28 & 41.25 \\
\hline $\mathbf{5}$ & 16.88 & 24.10 & 29.16 & 35.65 & 40.71 & 46.49 & 58.46 & 63.63 \\
\hline $\mathbf{6}$ & 20.43 & 32.01 & 40.12 & 50.53 & 58.65 & 67.91 & 87.12 & 95.41 \\
\hline $\mathbf{7}$ & 24.77 & 41.68 & 53.53 & 68.73 & 80.58 & 94.11 & 122.16 & 134.27 \\
\hline $\mathbf{8}$ & 29.78 & 52.84 & 68.99 & 89.73 & 105.89 & 124.33 & 162.58 & 179.09 \\
\hline $\mathbf{9}$ & 35.13 & 64.77 & 85.53 & 112.18 & 132.94 & 156.65 & 205.80 & 227.02 \\
\hline $\mathbf{1 0}$ & 40.46 & 76.63 & 101.98 & 134.51 & 159.86 & 188.79 & 248.79 & 274.69 \\
\hline
\end{tabular}




\begin{tabular}{|c|c|c|c|c|c|c|c|c|}
\hline \multirow{2}{*}{ t (hour) } & \multicolumn{8}{|c|}{ Return period (years)/flow rates $\mathbf{Q}\left(\mathrm{m}^{3} / \mathrm{s}\right)$} \\
\hline & $2 / 480$ & $5 / 834$ & $10 / 966$ & $25 / 1051$ & $50 / 1083$ & 100/1108 & $500 / 1115$ & $1000 / 1117$ \\
\hline 11 & 45.49 & 87.83 & 117.51 & 155.58 & 185.25 & 219.13 & 289.36 & 319.68 \\
\hline 12 & 49.92 & 97.68 & 131.16 & 174.10 & 207.58 & 245.79 & 325.03 & 359.22 \\
\hline 13 & 57.91 & 110.21 & 146.86 & 193.88 & 230.53 & 272.37 & 359.12 & 396.56 \\
\hline 14 & 60.65 & 116.31 & 155.32 & 205.38 & 244.39 & 288.92 & 381.27 & 421.12 \\
\hline 15 & 62.55 & 120.57 & 161.22 & 213.39 & 254.04 & 300.45 & 396.68 & 438.22 \\
\hline 16 & 63.49 & 122.64 & 164.10 & 217.29 & 258.75 & 306.07 & 404.21 & 446.56 \\
\hline 17 & 64.68 & 124.23 & 165.96 & 219.51 & 261.24 & 308.88 & 407.67 & 450.28 \\
\hline 18 & 64.20 & 123.16 & 164.49 & 217.51 & 258.79 & 305.90 & 403.59 & 445.75 \\
\hline 19 & 63.36 & 121.30 & 161.88 & 213.86 & 254.39 & 300.65 & 396.46 & 437.80 \\
\hline 20 & 61.86 & 117.94 & 157.14 & 207.44 & 246.61 & 291.26 & 383.87 & 423.83 \\
\hline 21 & 60.15 & 114.02 & 151.71 & 200.00 & 237.59 & 280.50 & 373.92 & 423.41 \\
\hline 22 & 57.85 & 108.82 & 144.51 & 190.12 & 225.69 & 266.26 & 378.94 & 428.97 \\
\hline 23 & 55.40 & 103.31 & 136.81 & 179.67 & 213.09 & 262.55 & 378.35 & 428.29 \\
\hline 24 & 52.50 & 96.79 & 127.71 & 167.34 & 200.82 & 255.48 & 368.87 & 439.47 \\
\hline 25 & 49.50 & 90.12 & 118.42 & 154.74 & 190.64 & 243.32 & 362.44 & 439.17 \\
\hline 26 & 46.30 & 82.98 & 108.50 & 141.26 & 176.01 & 225.85 & 350.03 & 417.78 \\
\hline 27 & 43.20 & 76.09 & 98.96 & 128.29 & 158.56 & 205.00 & 326.63 & 384.77 \\
\hline 28 & 40.14 & 69.25 & 89.49 & 115.42 & 138.71 & 181.30 & 295.54 & 342.73 \\
\hline 29 & 37.35 & 63.05 & 80.90 & 103.75 & 121.48 & 157.00 & 259.75 & 300.19 \\
\hline 30 & 34.75 & 57.25 & 72.86 & 92.84 & 108.33 & 131.60 & 221.57 & 256.58 \\
\hline 31 & 32.48 & 52.21 & 65.87 & 83.35 & 96.90 & 112.36 & 185.33 & 215.58 \\
\hline 32 & 30.42 & 47.63 & 59.53 & 74.74 & 86.51 & 99.96 & 149.44 & 175.23 \\
\hline 33 & 28.68 & 43.76 & 54.16 & 67.45 & 77.73 & 89.47 & 122.22 & 139.34 \\
\hline 34 & 27.14 & 40.35 & 49.44 & 61.03 & 70.00 & 80.24 & 107.53 & 117.65 \\
\hline 35 & 25.82 & 37.41 & 45.36 & 55.51 & 63.34 & 72.29 & 95.15 & 103.46 \\
\hline 36 & 24.66 & 34.84 & 41.80 & 50.68 & 57.53 & 65.34 & 83.97 & 92.13 \\
\hline 37 & 23.65 & 32.60 & 38.70 & 46.47 & 52.45 & 59.28 & 75.07 & 81.35 \\
\hline 38 & 22.55 & 30.18 & 35.35 & 41.92 & 46.98 & 52.74 & 65.48 & 70.97 \\
\hline 39 & 21.78 & 28.47 & 32.97 & 38.72 & 43.10 & 48.12 & 58.37 & 63.15 \\
\hline 40 & 20.86 & 26.42 & 30.14 & 34.87 & 38.47 & 42.59 & 50.80 & 54.31 \\
\hline 41 & 20.28 & 25.17 & 28.41 & 32.52 & 35.65 & 39.21 & 46.27 & 49.24 \\
\hline 42 & 19.59 & 23.64 & 26.28 & 29.65 & 32.18 & 35.07 & 40.73 & 43.10 \\
\hline 43 & 19.19 & 22.78 & 25.09 & 28.03 & 30.23 & 32.75 & 37.63 & 39.65 \\
\hline 44 & 13.69 & 15.88 & 17.41 & 19.35 & 20.87 & 22.60 & 26.20 & 27.75 \\
\hline 45 & 13.43 & 15.30 & 16.60 & 18.26 & 19.55 & 21.03 & 24.09 & 25.41 \\
\hline 46 & 13.05 & 14.46 & 15.44 & 16.68 & 17.65 & 18.75 & 21.05 & 22.04 \\
\hline 47 & 0.94 & 0.99 & 1.02 & 1.04 & 1.06 & 1.08 & 1.12 & 1.13 \\
\hline 48 & 0.94 & 0.99 & 1.02 & 1.04 & 1.06 & 1.08 & 1.12 & 1.13 \\
\hline 49 & 0.94 & 0.99 & 1.02 & 1.04 & 1.06 & 1.08 & 1.12 & 1.14 \\
\hline 50 & 0.94 & 0.99 & 1.02 & 1.04 & 1.06 & 1.08 & 1.12 & 1.14 \\
\hline 51 & 0.94 & 0.99 & 1.02 & 1.04 & 1.06 & 1.08 & 1.12 & 1.14 \\
\hline 52 & 0.95 & 0.99 & 1.02 & 1.04 & 1.06 & 1.08 & 1.12 & 1.14 \\
\hline Volume & 5.98 & 10.30 & 13.31 & 17.17 & 20.28 & 24.18 & 33.31 & 37.49 \\
\hline
\end{tabular}




\section{Results of MIKE 11-one dimension flood modelling}

Determining the areas risked by flood hazard in the area, the modelling methods were chosen by using the flood return period and the flood water level. With the aim of using 1D hydraulic modelling, MIKE 11 software powered by DHI was used in this study. In this model, the flood water level is obtained with the flood flow rates depending the flood return periods. The return period for simulation was specified with $52 \mathrm{~h}$, depending on the calculated flood flowrate data.

The flood level of area between Porsuk River and Eskisehir city was simulated with MIKE 11 according to 25, 50, 100, and 500 years-return period and possible flood flowrates. The simulation results obtained for specified periods are given in the Figure 6 by the result of MIKE View Program. The relation between return periodflood flow and the relation between the return period- flood water level are illustrated in the Figure 7.

When the flood return period is 25 years with $4 \%$ possibility, the flood flow rates are $1051 \mathrm{~m}^{3} / \mathrm{s}$ and the flood water will be observed in the river is $4.1 \mathrm{~m}$. In case of the return period is 50 years with $2 \%$ probability, flood flow rates equal to $1083 \mathrm{~m}^{3} / \mathrm{s}$ and the flood water levels are $4.3 \mathrm{~m}$. In case of the return period is 100 years with $1 \%$ probability, flood flow rates equal to $1100 \mathrm{~m}^{3} / \mathrm{s}$ and the flood water levels are $5.2 \mathrm{~m}$. If the flood return period is 500 years with $0.1 \%$ possibility flood flow rate danger from $1115 \mathrm{~m}^{3} / \mathrm{s}$ and the flood level will be observed in the river is $5.15 \mathrm{~m}$. As a result of onedimensional flood model of project area, it was stated that there is no linearity both between the return period and flood flow $\left(\mathrm{R}^{2}: 0.5826\right)$ and also between return period and flood water level $\left(\mathrm{R}^{2}: 0.4256\right)$.

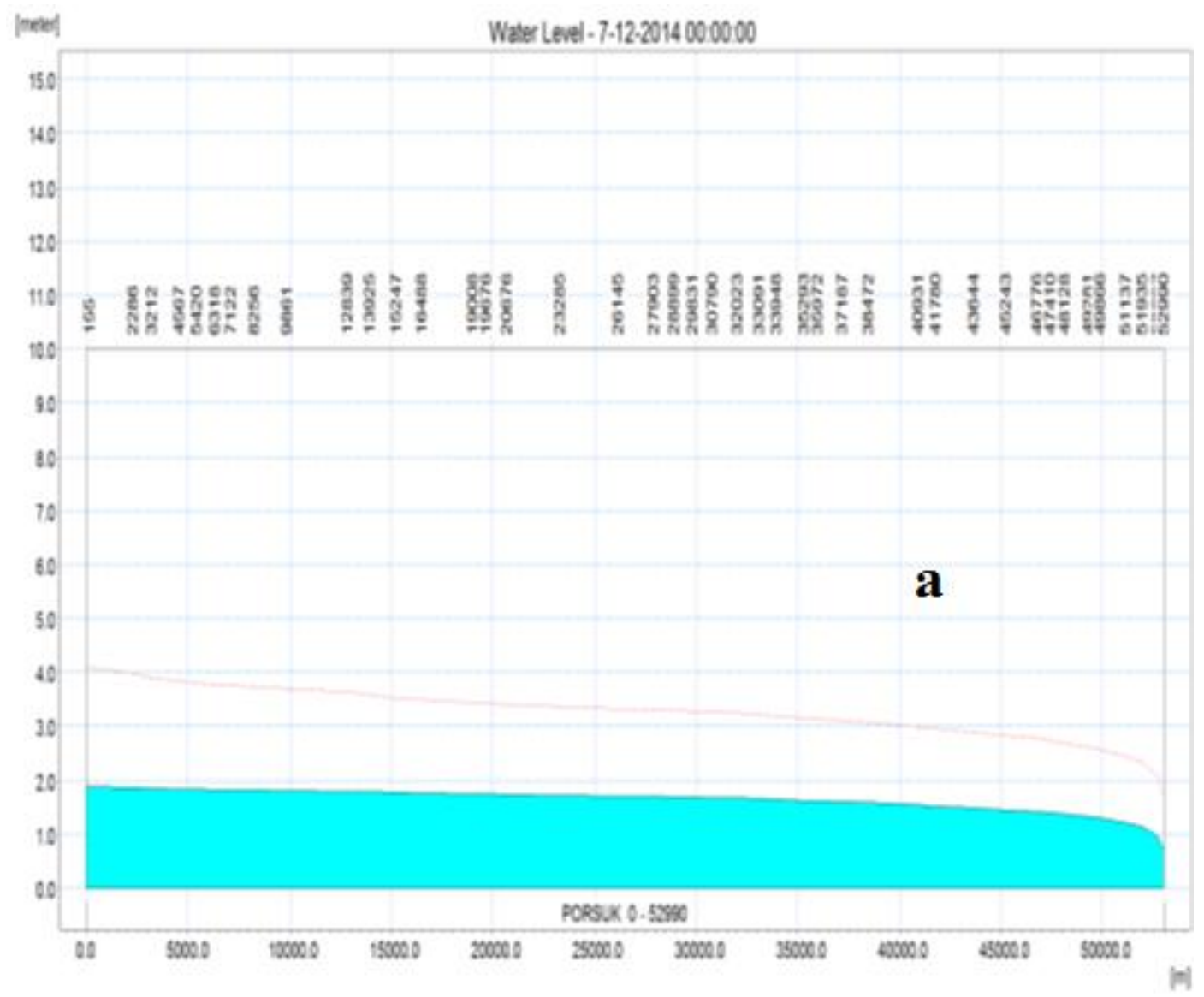



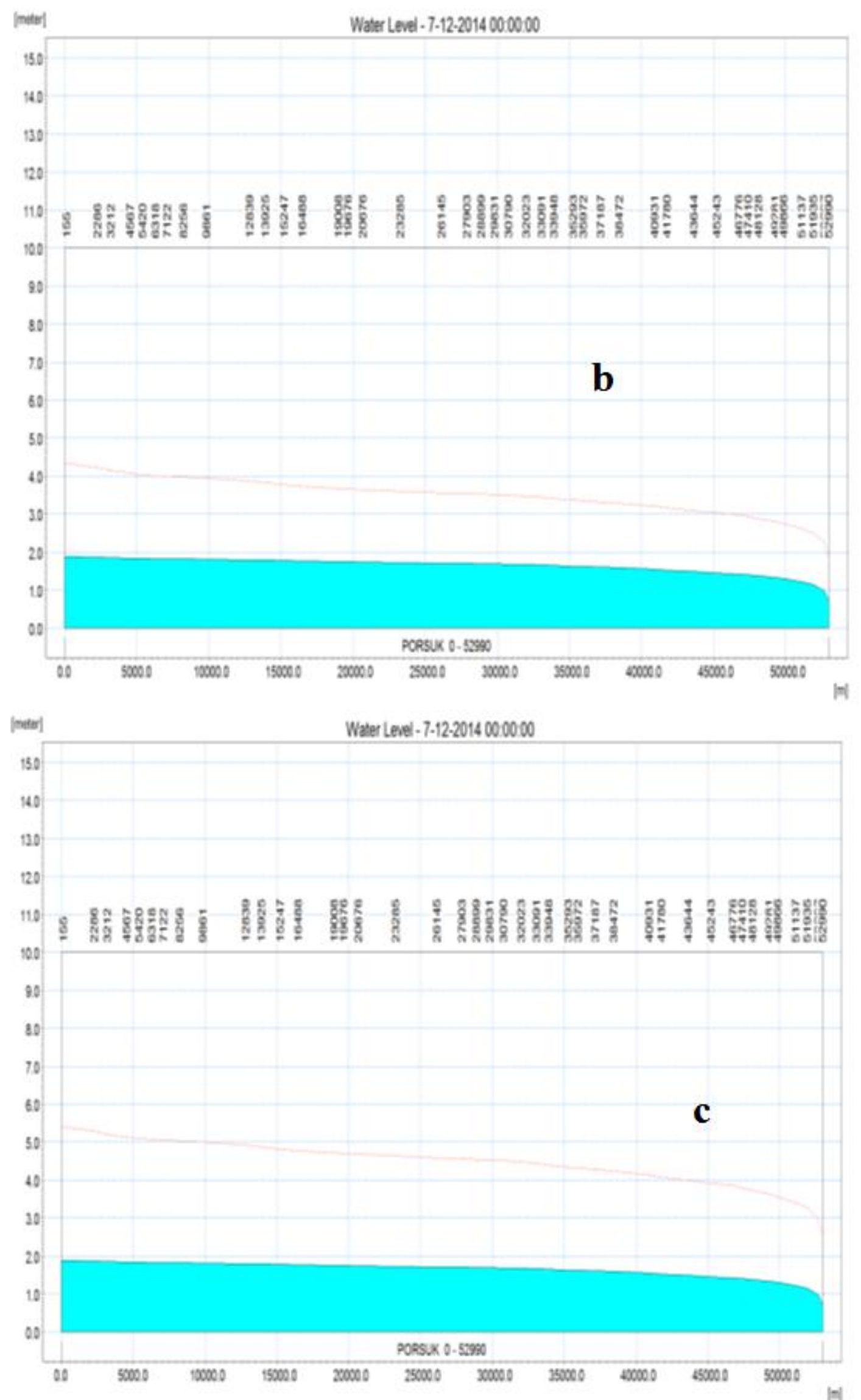

APPLIED ECOLOGY AND ENVIRONMENTAL RESEARCH 16(4):4969-4983. http://www.aloki.hu • ISSN 15891623 (Print) • ISSN 17850037 (Online) DOI: http://dx.doi.org/10.15666/aeer/1604_49694983 (C) 2018, ALÖKI Kft., Budapest, Hungary 


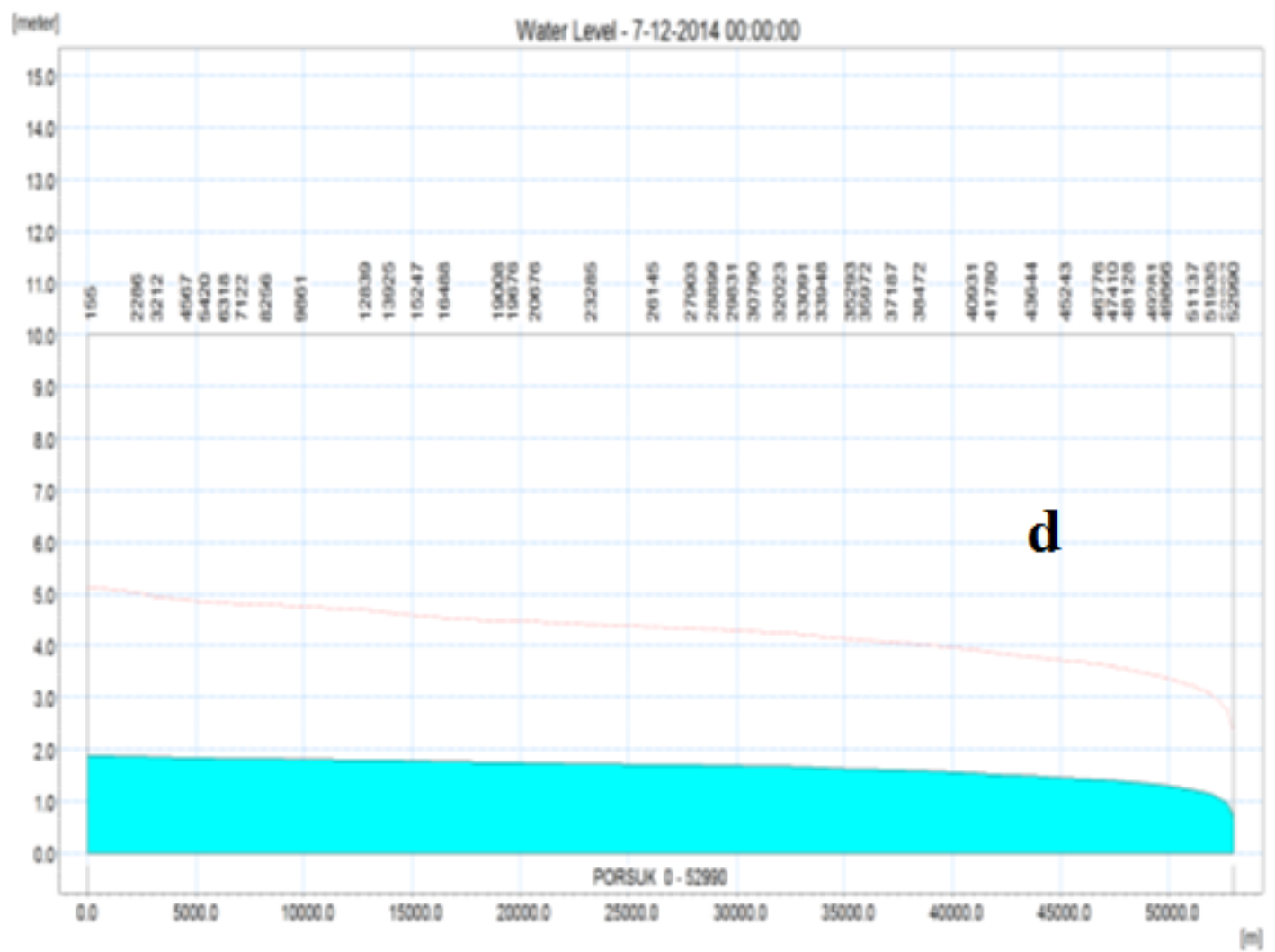

Figure 6. Results of MIKE 11-one dimension flood modelling for $25(\mathrm{a}), 50(\mathrm{~b}), 100(\mathrm{c})$ and 500 (d) years return periods

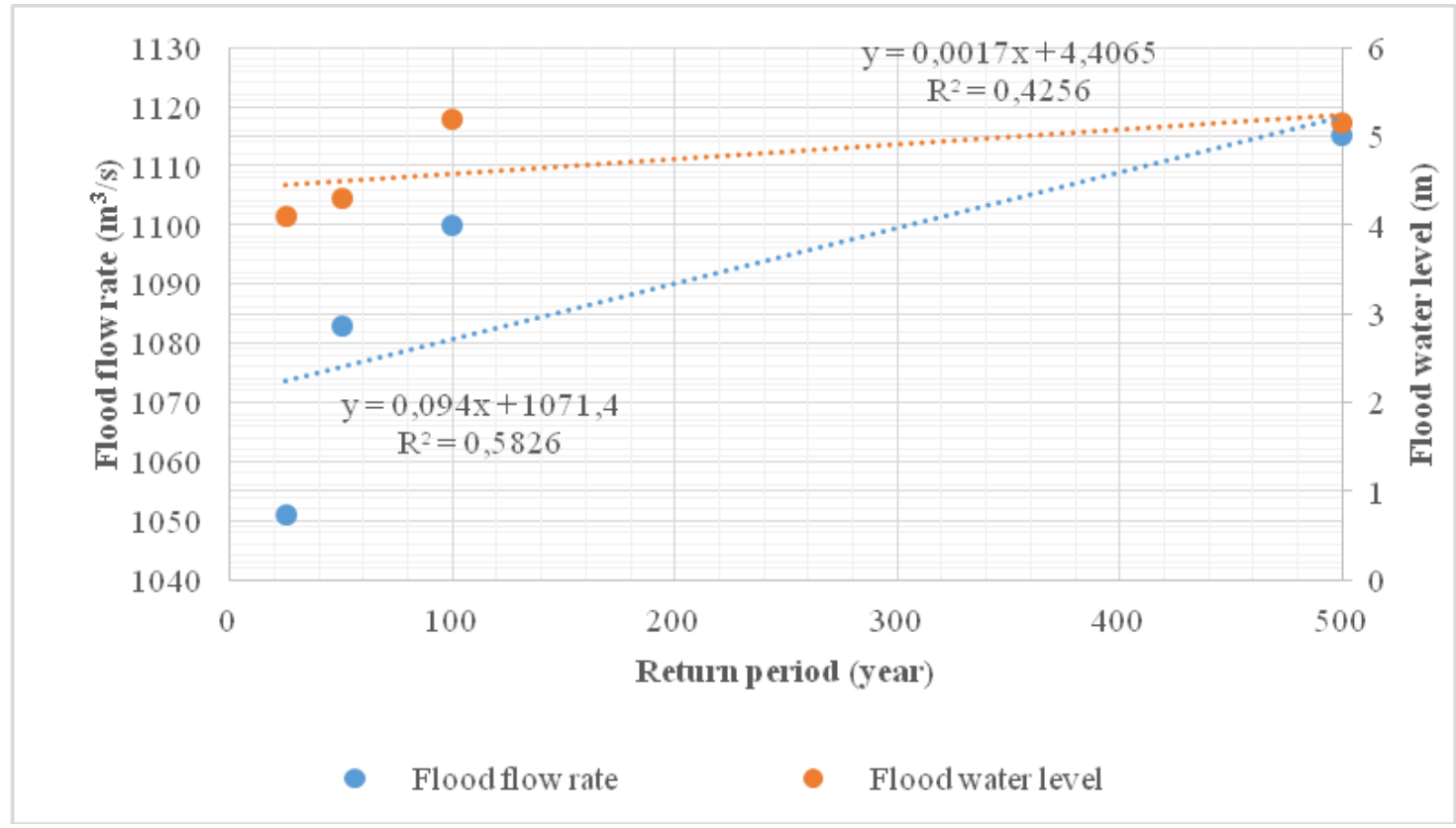

Figure 7. The relation between return period-flood flow and the relation between the return period-flood water level 


\section{Discussion}

Within the scope of the study, the necessary return period and flood size probability distribution were determined using flood frequency analysis for project area located in Porsuk Dam - Eskisehir City. Result of the flood frequency analysis, maximum possible flood flow rates were determined and these flow rates were used for one-dimensional model to determine flood water level. Validation and calibration studies were not performed in project area due to lack of real data of flood flow rate and flood water level. However, previous researchers performed validation and calibration studies of MIKE 11. Panda et al. (2010) calibrated MIKE 11 model for the monsoon periods of the years 2006 and 2001 and they stated that simulated flood levels by MIKE 11 one dimensional model fit real data in validation studies $\left(\mathrm{R}^{2}: 0.921\right)$ and calibration studies $\left(\mathrm{R}^{2}: 0.912\right)$. Also they determined that observed peak water levels in MIKE 11 fit better than other artificial neural network models because of their hidden neurons in the hidden layer (Panda et al., 2010). Haldar and Khosa (2015) stated that MIKE 11 hydrodynamic model was useful to diminish the flood risk level for river zone and they validated the model for the year 2000 with short available data.

Our results can be evaluated within the scope of the objectives of the National Flood Management Strategy for other settlement which have flood risk. There are similar researches in literature especially in Europe. Booij (2003) argued that decision support systems could be used to select the plan to be used for flood control and ecosystem rehabilitation. In his study, he created the model environment for the Red River basin aiming decision support system usage. Meteorological, hydrological, hydraulic, social and economic data of Red River were used to the PCRaster system. Also Birkland et al. (2003) emphasized that the environmental damage caused by floods in river ecology has increased due to the inadequate flood hazard control policies, and the environmental, social and environmental impacts of flood risk areas have been increasing in order to improve ecosystem functions, protect sensitive environmental resources, they argued that local governments should take an active role in creating an optimized flood management policy from economic approaches.

Akadiri et al. (2008) aimed to improve the resilience of the buildings located on the coast of England against flood in his study. He listed the factors affecting flood risk as soil type, basic geological structure and humidity conditions of existing soil, density of precipitation, average annual precipitation, rainfall transport capacity of the channel and precipitation regime. He stressed that the most serious effects created by climate change are accelerated sea level rise and greater coastal overflow due to rising winds. DEFRA cited increased flood numbers with climate change by referring to 2004 data. Again based on this data; the preliminary views on the total number of domestic, industrial and commercial buildings under flood risk, the human population to be affected by flood risk, the total value of vulnerable agriculture areas against floods, annual average flood protection and costs to avoid losses. The homeowners ranked flood-resistant buildings with proposals increase the defense strength of their buildings against floods. The one dimensional model created in the study can be used as a base and 2D and integrated models can be created for Porsuk Dam - Eskisehir City. Flood frequency analysis performed in this study; Porsuk Dam - Eskişehir City can be used for engineering purposes in the design of bridges, dams, culverts and flood control structures. It also provides the necessary data to determine the economic value of flood control projects, clarify the flood deposits and determine the area on the flood bed. 
In this study, the area between Porsuk Dam, which is source drinking water source of project area, and Eskisehir was simulated to investigate flood risk and flood frequency analysis and flood water level was determined by MIKE 11 model. Flood frequency analysis performed in this study for area between Porsuk Dam- Eskisehir. The results of one-dimension flood model can be used for engineering purposes to design urban basins, dams, culverts and flood control of these structures. In addition to determining the economic value of flood control projects, the results of MIKE 11 model provide efficient, easy and quick response in the case of emergency action against flood risk to reduce flood detrimental effects.

Formation of flood risk maps and flood protection schemes of our country, which is taking important steps in the process of accession to the European Union, is ultimately required in accordance with the Council of Europe and the European Parliament Directive 2007/60/EC of October 23, 2007 on Flood Risk Assessment and Management. For all these reasons; In areas under flood risk; appropriate flood prevention structures should be determined by investigating the environmental, social and economic effects that floods can create, creating flood risk maps, flood intervention and prevention plans of risky areas in water and river basins.

Acknowledgements. This study was supported by Anadolu University Scientific Research Project Commission under Grand Number with 1210F157.

\section{REFERENCES}

[1] Akadiri, O., Okoje, V., Arotiba, J. (2008): Identification of risk factors for short-term morbidity in third molar surgery. - Odonto-Stomatologie Tropicale $=$ Tropical Dental Journal 31(124): 5-10.

[2] Akpınar, A. (2013): İklim Değişikliğinin Deniz Taşkınları Üzerindeki Etkilerinin Araştırılması. - 3. Ulusal Taşkın Sempozyumu, İstanbul.

[3] Aras, M., Fındık, S., B. (2013): Avrupa Birliği Taşkın Direktifi ve Ülkemizde Taşkın Direktifi Hususunda Yapılan Çalışmalar. - S. Y. G. M. Orman ve Su İşleri Bakanlığı, Taşkın ve Kuraklık Yönetim Planlaması Dairesi Başkanlığı. İstanbul.

[4] Birkland, T. A., Burby, R. J., Conrad, D., Cortner, H., Michener, W. K. (2003): River ecology and flood hazard mitigation. - Natural Hazards Review 4(1): 46-54.

[5] Booij, M. J. (2003): Determination and integration of appropriate spatial scales for river basin modelling. - Hydrological Processes 17(13): 2581-2598.

[6] Brown, J. D., Damery, S. L. (2002): Managing flood risk in the UK: towards an integration of social and technical perspectives. - Transactions of the Institute of British Geographers 27(4): 412-426.

[7] Calder, I. R., Aylward, B. (2006): Forest and floods: Moving to an evidence-based approach to watershed and integrated flood management. - Water International 31(1): 8799.

[8] Çetin, N. İ., Tezer, A. (2013): ABD, Avrupa Birliği ve Türkiye'de Sel Risk Yönetiminin Karşılaştırılması. - 3. Ulusal Taşkın Sempozyumu. İstanbul.

[9] Düzgün, H., Ş. (n.d.): Taşkın Risk Yönetimi. - Jeodezi ve Coğrafi Bilgi Teknolojileri. ODTU-Maden Müh. Böl.

[10] Griffiths, M. (2002): The European Water Framework Directive: an approach to integrated river basin management. - European Water Management Online 5: 1-14.

[11] Haldar, R., Khosa, R. (2015): Flood level mitigation study using 1-D Hydrodynamic modeling. - Aquatic Procedia 4: 925-932. 
[12] Haltaş, İ., Tayfur, G., Elçi, Ş., Güney, Ş., Bombar, G. (2013): Ürkmez Barajı Baraj Yıkılması Sonrasında Taşkın Yayılımının Sayısal Modeli ve Fiziksel Model Kıyaslaması. - 3. Ulusal Taşkın Sempozyumu. İstanbul.

[13] Hopur, B. (2013): Ulusal Havza Yönetim Stratejisi. - 3. Ulusal Taşkın Sempozyumu, İstanbul, T. C. Orman ve Su İleri Bakanlığı.

[14] Liu, H.-L., Chen, X., Bao, A.-M., Wang, L. (2007): Investigation of groundwater response to overland flow and topography using a coupled MIKE SHE/MIKE 11 modeling system for an arid watershed. - Journal of Hydrology 347(3-4): 448-459.

[15] Marchi, L., Borga, M., Preciso, E., Gaume, E. (2010): Characterisation of selected extreme flash floods in Europe and implications for flood risk management. - Journal of Hydrology 394(1): 118-133.

[16] Merz, B., Hall, J., Disse, M., Schumann, A. (2010): Fluvial flood risk management in a changing world. - Natural Hazards and Earth System Science 10(3): 509-527.

[17] Morss, R. E., Wilhelmi, O. V., Downton, M. W., Gruntfest, E. (2005): Flood risk, uncertainty, and scientific information for decision making: lessons from an interdisciplinary project. - Bulletin of the American Meteorological Society 86(11): 1593.

[18] Özdemir, O., N. (2013): HEC serisi programlarla Ardışık barajların taşkın önleme amaçlı işletilmesi Seyhan Havzasında Çatalan-Seyhan barajları örneği. - 3. Ulusal Taşkın Sempozyumu İstanbul.

[19] Panda, R. K., Pramanik, N., Bala, B. (2010): Simulation of river stage using artificial neural network and MIKE 11 hydrodynamic model. - Computers \& Geosciences 36(6): 735-745.

[20] Patro, S., Chatterjee, C., Mohanty, S., Singh, R., Raghuwanshi, N. (2009): Flood inundation modeling using MIKE FLOOD and remote sensing data. - Journal of the Indian Society of Remote Sensing 37(1): 107-118.

[21] Thompsona, J. R., Sørenson, R., Gavina, H., Refsgaar, A. (2004): Application of the coupled MIKE SHE/MIKE 11 modelling system to a lowland wet grassland in southeast England. - Journal of Hydrology 293: 151-179.

[22] Tingsanchali, T., Karim, M. F. (2005): Flood hazard and risk analysis in the southwest region of Bangladesh. - Hydrological Processes 19(10): 2055-2069.

[23] Tiryaki, B. (2013): DSİ Taşkın Yönetim Çalışmları ve İçerisinde İşletme ve Bakım Faaliyetlerinin Yeri. - 3. Ulusal Taşkın Sempozyumu. İstanbul, Orman ve Su İşleri Bakanlığı Devlet Su İleri Genel Müdürlüğü.

[24] Uşkay, S., Aksu, S. (2002): Ülkemizde taşkınlar, nedenleri, zararları ve alınması gereken önlemler. - Türkiye Mühendislik Haberleri (420-421): 422.

[25] Ün, Y. (2013): Türkiye'de Taşkın Gerçeği ve Metorolojik Erken Uyarı Sistemleri. - 3. Ulusal Taşkın Sempozyumu, İstanbul, T. C. Orman ve Su İşleri Bakanlığı.

[26] Wen, L., Macdonald, R., Morrison, T., Hameed, T., Saintilan, N., Ling, J. (2013): From hydrodynamic to hydrological modelling: Investigating long-term hydrological regimes of key wetlands in the Macquarie Marshes, a semi-arid lowland floodplain in Australia. Journal of Hydrology 500: 45-61.

[27] Wolfs, V., Willems, P. (2013): A data driven approach using Takagi-Sugeno models for computationally efficient lumped floodplain modelling. - Journal of Hydrology 503: 222232 .

[28] Zhang, H., Ma, W.-C., Wang, X.-R. (2008): Rapid urbanization and implications for flood risk management in hinterland of the Pearl River Delta, China: The Foshan study. Sensors 8(4): 2223-2239. 